\title{
Emerging Rules in International Investment Instruments and China's Reform of State-owned Enterprises
}

\author{
Qingjiang Kong \\ Professor, Collaborative Innovation Centre for Territorial Sovereignty and \\ Maritime Rights, China University of Political Science and Law, China \\ qkong20oo@hotmail.com
}

\begin{abstract}
The recent years witnessed the emergence of international investment agreements (IIAs), such as the U.S. model BIT in 2012, and more prominently, the Trans-Pacific Partnership (TPP) in 2015, which often embody provisions for state-owned enterprises (sOEs). The soE rules, as well as their predecessor, the oECD Guidelines on Corporate Governance of State-Owned Enterprises, aim to impose strict regulations on the soes and to exert great influence on the state-led economies. China has been seen in constant reform of its SOEs, and is now in the midst of negotiating a BIT with, and the U.s., and a BIT with the European Union. Against this backdrop, China's soe reform will be relevant to the emerging investment rules governing soEs.
\end{abstract}

\section{Keywords}

state-owned enterprise - reform - state-led economy - international investment agreements 


\section{Introduction}

China was the largest recipient of inbound direct investment and the third largest source of outbound direct investment in 2014. ${ }^{1}$ As China's economy has indivisible relationship with state-owned enterprises (soes), Chinese soes may have a tangible influence on the inbound direct investment, and play a formidable role in the outbound direct investment.

The country has been seen in constant reform of its SOEs, with the Guidelines of the Central Committee of Chinese Communist Party and the State Council on the Deepening of State-owned Enterprise Reform (soE Reform Guidelines) ${ }^{2}$ as the latest blueprint for such reform. Against this backdrop, China's reform of soEs will be relevant to the emerging international investment rules as exhibited in the international investment instruments such as bilateral investment agreements and free trade agreements (particularly where both China and its partners like the United States and the EU that are busy negotiating investment rules in the form of BITs or FTAs). It is also interesting to see how the emerging investment rules will affect the Chinese agenda for soE reform. I will first examine the emerging international investment rules as exhibited in the new international investment instruments (IIAs) and then the trajectory chart of China's SOE reform and the rationale thereafter. I will then explore what impact the soe provisions will project, and extrapolate, in particular, the implications of the state-led economy denomination in investment rules. In the end, the author will discuss the policy consideration regarding how China should handle negotiation surrounding the soEs issue.

\section{Emergence of International Investment Rules Governing soEs}

\subsection{Background of the Emerging SOEs Rules in IIAS}

Regulation of SOEs is in connection with the mainstream Western economics that has constantly belittled the governments' roles in economy. ${ }^{3}$ soes exist

1 MOFCOM, 2014 Statistical Bulletin of China's Outward Foreign Direct Investment, downloadable at http://fec.mofcom.gov.cn/article/tjsj/tjgb/201512/20151201223579.shtml, at 89, and 85. The Bulletin is downloadable at http://fec.mofcom.gov.cn/article/tjsj/tjgb/201512/ 20151201223579.shtml.

2 Available at http://www.sh.xinhuanet.com/2015-09/14/c_134620921.htm.

3 The mainstream economics in the West is liberalism, which emphasizes on free competition and the role of law of value in the market, opposes to government intervention and advocates free trade, free production and free business. The founder of liberalism is Adam Smith, 
in all countries, are used for different purposes, and are regulated and managed in widely varying ways. Some soes provide public services, but in other times, extensive government participation in economies through soEs can distort competition to the detriment of private firms and their workers. This can occur through soes that receive advantages from governments, such as preferential financing, including through State-owned banks; provision of goods or services from the government or from other soEs at preferential prices or free of charge; direct subsidies and debt forgiveness, or other preferences. These preferences can tilt the playing field in favor of soEs and against foreign firms. Against the backdrop, concerns have been raised about the nations that organize economic activities through soEs, or via the mechanism to influence and control the latter or championed private enterprises. Some countries that maintain many soes are already considering reforms to enhance the efficiency and productivity of their economies.

Concerns about the role of soes have grown increasingly in recent years because soes that had previously operated almost exclusively within their own territories are increasingly engaged in international trade of goods and services or acting as investors in foreign markets. What is worse, even where enforcement against soEs in foreign markets has been pursued for anti-competitive behavior or other unlawful behavior, commercial soes have avoided prosecution by claiming sovereign immunity. In the Chinese context, for example, soes not only assume a formidable role in the domestic economy, but are the main subjects in the overseas investment. Chinese soes have grown rapidly as actors in global trade, in cross-border investment. Whereas in 2000, there was only one Chinese SOE in the Fortune Global 500 list of the largest companies in the world, now there are to $87 .{ }^{4}$ Their international activity and more importantly, their unrivalled competition have raised greater concerns about government influence, potential trade distortions, and unfair competition, which boils down to the fact that soes-based investment pattern is the extension of Chinese state-led economy model.

Against this backdrop, by interacting with scholars, U.s. government has form theoretical foundation on the judgments of state-led economy. Currently,

who pointed out that the merchants are guided by an invisible hand to achieve a goal that may not be their own purposes. Despite that, it may be a different thing for the society. It will more efficiently promote the society's interest by pursuing own interest than by pursing the society's interest. See Adam Smith: The Wealth of Nations, edited by Charles Elliot, translated by Ran Mingzhi, Beijing Institute of Technology Press 2013, p. 326.

4 See Xinhua News Agency, More Chinese firms in Fortune 500, 24 July 2015, available at http:// news.xinhuanet.com/english/china/2015-07/24/c_134442549.htm. 
Western countries are actively engaged in initiating new rules including domestic laws and IIAs to contain the international activities of soes. ${ }^{5}$ Among the countries with efforts to contain foreign soes, the U.S. is a leader in initiating international rules for soEs. Its intention in this regard became clearer when the U.S. model BIT replaced the previous model, i.e., the 2004 model BIт. ${ }^{6}$ The 2012 model BIт has provisions that, as shown below, were designed to target some activities of soEs. The Trans-Pacific Partnership (TPP) provided an excellent opportunity for the U.s. to systematically address the emerging concerns relating to the soEs, including financing and subsidization of soes involved in exporting, domestic competition for business and contracts; and regulatory policies which, by design or because of lack of transparency, create inherent advantages for soes favored by home governments. ${ }^{7}$

\subsection{The oECD's SOE Guidelines}

In 2005, OECD issued the Guidelines on the Corporate Governance of StatedOwned Enterprises. ${ }^{8}$ The OECD's SOE Guidelines were updated in 2015 to take into account developments since their adoption and to reflect the experiences of the growing number of countries that have taken steps to implement them. The OECD Guidelines, which are not binding per se, are not IIAs. They can only be called soft law ${ }^{9}$ in the form of recommendations to the OECD members and beyond. The OECD guidelines aim to: (i) professionalise the state as an owner;

5 Paul Blychak, State-Owned Enterprises and International Investment Treaties When are State-Owned Entities and their Investments Protected? 1 Journal of International Law and International Relations Vol. 6, No. 2, pp. 1-52.

6 The 2012 Model BIт retains the core protections set forth in the 2004 Model BIT while also making several significant changes designed to provide broader protections for American investors, to ensure greater transparency, and to expand labor and environment rights. The 2012 Model BIT attempts to balance investor protections while preserving the Government's ability to regulate in the public interest. Public reactions to the new BIT were mixed, as expected. Noteworthily, there are in the 2012 Model BIT, new provisions targeting the activities of SoEs.

7 Suyoshi Kawase, Trans-Pacific Partnership negotiations and rulemaking to regulate state-owned enterprises, 29 July 2014, http://voxeu.org/article/trans-pacific-partnershipnegotiations-and-rulemaking-regulate-state-owned-enterprises.

8 See oEcD Guidelines on the Corporate Governance of Stated-Owned Enterprises, available at http://www.oecd-ilibrary.org/docserver/download/2615061e.pdf?expires=1480598525\&id=id \&accname=guest \&checksum $=528 \mathrm{CCC}_{6} \mathrm{~F}_{7} \mathrm{DB}_{9} \mathrm{E}_{7} \mathrm{C}_{25} \mathrm{E}_{3} 62921622 \mathrm{~B} 95 \mathrm{~A}_{5}$.

9 Guzman, Andrew T. and Meyer, Timothy, International Soft Law (August 4, 2010). The Journal of Legal Analysis, Vol. 2, No. 1, Spring 2011; UC Berkeley Public Law Research Paper No. 1353444. Available at sSRN: https://ssrn.com/abstract=1353444 or http://dx.doi.org/10.2139/ ssrn.1353444. 
(ii) make soes operate with similar efficiency, transparency and accountability as good practice private enterprises; and (iii) ensure that competition between soes and private enterprises, where such occurs, is conducted on a level playing field. In other words, these Guidelines give concrete advice to countries on how to manage more effectively their responsibilities as SOE owners, thus helping to make soes more competitive, efficient and transparent. The Guidelines identify several problems of soEs' governance under a stateled economy system, but do not address whether certain activities are best placed in public or in private ownership. However, if a government decides to divest SOEs then good corporate governance is an important prerequisite for economically effective privatisation, enhancing soE valuation and hence bolstering the fiscal proceeds from the privatisation process. ${ }^{10}$

\subsection{Some Highlights of SOE Rules in U.s. Model BIT 2012}

It is difficult what kind of impact the OECD's Guidelines of 2005 had on the formation of the U.s. Model BIT 2012. However, it is safe to say that the OECD's SOE Guidelines did have impact on the latter. The following are highlights of SOE rules in U.S. Model BIT of 2012:

\subsubsection{Domestic Technology Requirement}

Domestic technology requirement refers to such policies that allow domestic investors, and soes in particular, to gain competitive advantages by requiring the government to purchase, use or accord a preference to, particular technology in its territory. ${ }^{11}$ In the 2012 model BIT, a series of new rules have been designed to avoid domestic technology requirement on government procurement. These rules may have the intention of restricting the innovation policy in China.

1.3 .2

Participation in Technical Rule-Making and Product

Standard-Setting

If product standards of the foreign markets are made in an opaque and unpredictable environment, or even in a discriminatory way, especially when the host governments apply the standards or technical regulations for the competitive advantages of its corporations or technologies, the foreign investors will be in a biased condition. To avoid that, the 2012 model BIT incorporated a provision that the foreign investors participate in the development of standards and technical regulations on terms no less favorable than those it accords to

10 OECD Guidelines on the Corporate Governance of Stated-Owned Enterprises, at 11.

11 The U.S. 2012 BIT model Article 8.1(8). 
domestic enterprises. This requirement is also applied to non-governmental standardizing bodies. ${ }^{12}$

\subsubsection{SOEs with Governmental Authority}

Before 2012 BIT model, there had not been a clear definition of soEs with governmental authority. And because of the vague definition, it was likely to cause controversies over what soEs should be regulated by BITs. It is not difficult to find that in the 2004 model BIT, no consensus was reached that soEs should be regulated, even though the state-led-economy issue has been under discussion in the later BIT negotiations. ${ }^{13}$ The ambiguity and ambivalence suggested that the U.s. government then did not have the intent to regulate investment of soEs, while on the other hand, it did not rule out the possibility that a country may be held liable for the actions conducted by the soes with governmental authority, even in an unofficial manner. The 2012 BIT model use a footnote to clarify that delegable governmental authority includes a legislative grant, and a government order, directive or other action transferring to the state enterprise or other person, or authorizing the exercise by the state enterprise or other person of, governmental authority. It is then clear that soes fall within the scope of BITs.

\subsection{Layouts of a Comprehensive Set of SOE Rules in TPP}

Understandably, stat-led economies and the state-led model investment pattern are longing for respect and recognition. Since the state-led economy issue involved many aspects of bilateral investment, inter alia, national security, it cannot be more certain that the West, particularly the U.s., will not recognize Chinese soEs as welcomed investment entities. The exclusion of China from the negotiation of a TPP and conclusion of SOE chapter in the TPP are the illustrative evidence. As a matter of fact, the TPP goes so far as to address the distortions soes can cause in the market. It is the first Free Trade Agreement (FTA) to seek to address comprehensively the commercial activities of soes that compete with private companies in international trade and investment.

\subsubsection{Broad Coverage}

TPP's SOE chapter provides broad coverage of soEs that are principally engaged in commercial activity. At the same time, to avoid an outcome in which a government could easily evade its obligations by delegating its authority to an

\footnotetext{
12 The U.S. 2012 BIT model Article 11.8.

13 The U.S.-Uruguay BIT 2006 contains regulations concerning state-owned enterprises, such as Article 2.2.
} 
SOE, it includes rules requiring soEs that operate under delegated authority to abide by the obligations of the TPP Agreement.

\subsubsection{Commercial Consideration and Non-Discrimination}

The SOE chapter requires TPP Parties to ensure that their soes make commercial purchases and sales on the basis of commercial considerations, except when doing so would be inconsistent with any mandate under which an SOE is operating that would require it to provide public services. TPP governments also agree to ensure that their soes or designated monopolies do not discriminate against the enterprises, goods, and services of other Parties.

\subsubsection{Immunity and Impartial Regulation}

The SOE chapter includes obligations requiring TPP countries to provide their courts with jurisdiction over commercial activities of foreign soes so that a foreign SOE operating in a TPP country could not evade legal action regarding its commercial activities merely by claiming sovereign immunity. At the same time, it includes rules requiring Parties to ensure that administrative bodies regulating both soes and private companies do so in an impartial manner and do not use their regulatory authority to provide preferential treatment to their SOES.

\subsubsection{Non-Commercial Assistance}

The SOE chapter ensures that, in providing any non-commercial assistance to SOEs, TPP Parties agree to not cause adverse effects to the interests of other TPP Parties. This includes a commitment from TPP Parties to not cause injury to another Party's domestic industry by providing non-commercial assistance to a soe that produces and sells goods in the territory of another Party.

\subsubsection{Transparency}

Having access to information about the soes of the TPP Parties and their activities is critical to ensuring the outcomes we hope to achieve through this chapter. Toward this end, the chapter requires TPP Parties to share a list of their SOEs with the other TPP countries and provide, upon request, additional information about the extent of government ownership or control and the non-commercial assistance they provide to soes.

\subsubsection{Exceptions}

TPP recognizes, defines, and ensures legitimate roles for soEs in provision of public services. The chapter establishes exceptions to the commitments on soes. For example, nothing in this chapter would prevent a Party from taking 
prudential measures or other measures to respond temporarily to an economic emergency. In addition to the exceptions that apply to all Parties, a set of country-specific Annexes define narrowly-tailored and country-specific exceptions to specific obligations as well as transition periods to provide certain countries additional time to meet the obligations of the chapter.

\subsubsection{Dispute settlement}

SOE rules are fully enforceable, subject to State-to-State dispute settlement. Investor-state dispute settlement does not apply to the soE rules.

\section{Chinese soE Reforms and the State-led Economy}

\subsection{The Trajectory Chart of Chinese soE Reform ${ }^{14}$}

From the late 1970s on, the Chinese leadership launched market-oriented reform. In the pre-reform era, all the soes were fitted into the Soviet mould of central planning, under which large-sized enterprises were placed under the direct leadership of central departments of the state, and all the others were subjected to the local government departments..$^{15}$ soes had little or no competence in matters ranging from labor recruitment, finance and disposition of property to production, supply and marketing. In reference to the relationship between soes and the state, a Chinese scholar pointed out that 'their (soes') production was controlled by (state) mandatory planning, materials and fund allocated by the state, products distributed by the state, profits rendered to the state which also takes responsibility for their loss. Enterprises had no autonomy and needed none. ${ }^{16}$ Actually, they were, in the Chinese jargon, 'administrative appendages' to different departments at different levels.

In the reform era, one of the objectives of the reform has been to revive the soEs. In its initial stage (from 1978 to 1984 ) the reform brought soEs some

14 This part is an extended and updated research on the basis of the author's previous study on soe reform, see Qingjiang Kong, Quest for Constitutional Justification: Privatization with Chinese characteristics, Journal of Contemporary China (2003), 12:36, 537-551.

15 It is interesting to note that the commonly used term 'soEs' was called 'state-run enterprises' before reform was begun and even long after reform was implemented. It was after the 14th Party Congress in 1992 that the term 'state-run enterprises' was replaced by 'state-owned enterprises'. In 1993 the Constitution was amended, among other things, to this end. The evolution of the term clearly reflected the long-lasting impact of the Soviet model.

16 See Jiang Yiwei, 'Enterprises reform', in Peter Nolan et al. (eds), The Chinese Economy and Its Future: Achievements and Problems of Post-Mao Reform (1990), p. 154. 
autonomous power. ${ }^{17}$ SOEs gradually assumed more power, which smoothed their operation. However, as one Chinese scholar observed, one notable defect of the SOE reforms is that the powers granted to the soes were often in the form of administrative authorization. In other words, powers of the soes were sourced in administrative authorities, not in the nature of private law rights. ${ }^{18}$ As a result, the powers of soes were not secure in terms of continuity because such administrative authorization fluctuated greatly according to changing political climate, and was susceptible to administrative interference. More critical was that no reference could be found to the soes' right to property under their operational management. Though, at this stage, the notion of legal person (faren) was borrowed, which partially legitimated the soes to exercise the lawful function of possessing, utilizing and disposing of the property entrusted to them by the state for operation and management, it was far from its original meaning. From the legal point of view, the reason for the shortcoming of the reform lay in the fact that it failed to touch the fundamental issue, i.e. the right to property by a free legal entity. Unfortunately, in the context of orthodox socialist ideology the failure is irreparable.

With a view to avoiding an ideological clash, the shareholding system was introduced. It was deemed to be able to permit the re-organization of the ownership system, while helping to avoid a de jure privatization. The shareholding system began with the experimentation of raising funds for collective enterprises. Bao'an Co. Ltd, an investment company based in Shenzhen, one of five Special Economic Zones in China, was the first to issue shares to the public in 1983. The 1983 Interim Provisions on Several Policy Issues granted official authorization for such experimentation concerning the urban collective economy. ${ }^{19}$

17 The power accorded to the soes was initially termed as 'autonomous right of operational administration'. See the State Council, Certain Measures Concerning Expanding Operational Administration Autonomy of State-run Enterprises. This term was incorporated in the 1982 Constitution, Article 16(1) of which reads: 'The state-run enterprises enjoy autonomous right of operational administration subject to the law, provided they subject themselves to the unified leadership of the State and have fulfilled all the State plans'. This provision was amended. The requirement of 'subjecting themselves to unified leadership of the State and fulfilling all the State plans' was dropped, and the term 'autonomous right of operational administration' was replaced with 'right to autonomous operation'.

18 See Jianfu Chen, From Administrative Authorization to Private Law, A Comparative Perspective of the Developing Civil Law in The People's Republic of China (Dordrecht: Nijhoff, 1995), p. 87.

19 See, Ibid., p. 198. 
It was not until 1984 that the CPC Central Committee endorsed a landmark decision on reform of economic structure to deal with, inter alia, non-public ownership. Apparently, due to the ideological limitation, the decision only mentioned 'developing diversified economic forms' - instead of private ownership. While strengthening the dominance of public ownership, it proclaimed that other economic entities were a helpful complement to the public sector. Another noteworthy point is that it gave a fresh explanation to the notion of legal person. ${ }^{20}$

In the meantime soes were allowed to raise funds through the shareholding system. Large-sized soes were authorized to issue shares to their own employees. Small-sized soes were even allowed to convert themselves into collective enterprises by issuing shares. The experiment was so popular in some localities that the local governments promulgated their own rules to regulate the issuance of shares by soEs and other enterprises. A leading economist, Li Yining, predicted that, as in the case of the household contracting system replacing People's Communes in rural areas, shareholding companies would eventually replace all soEs. ${ }^{21}$ His prediction proved later to be over-optimistic. In early 1987, soon after Hu Yaobang, the reform-minded and pro-democracy Communist Party General Secretary was forced to step down under an attack from the leftists, the economic as well as political atmosphere became austere. As a result, the experimentation of the shareholding system in the soes was put to an end. That year the State Council issued a notice regarding strengthening administration of shares and bonds, under which the issuance of shares was to be restricted to the collective enterprises approved on a trial basis.

Fortunately, the anti-reform move was curbed before it could have time to have an impact on SOE reform. The ideological breakthrough came from the thirteenth Party Congress in 1987. The party proclaimed that China was still in a 'primary stage of socialism', in which 'it is particularly important to develop diverse sectors of the economy, provided that public ownership remains dominant; to have diverse forms of distribution, provided that distribution to each according to his work (an lao fenpei) is the principal form; and with the objective of common prosperity in mind to encourage some people to become welloff first through honest work and lawful business operations'.

20 In this regard the decision declared, from the utter utilitarian point of view, that ownership could be duly separated from the right of operation with a view to eliminating the contradiction between the notion in theory and that in practice. The new explanation was later recognized by Article 41 of the 1986 General Principles of Civil Law, the PRC's first civil law since 1949 .

21 See, Chen, From Administrative Authorization to Private Law, p. 199. 
This ideological guideline had some in-depth impact on ownership. Firstly, it endorsed the development of different forms of ownership by allowing the private sector to come into existence. Due to the operational difficulty, the development of the private sector turned out unchecked in the following years, even though the guideline stated clearly that public ownership remain dominant. In some regions, e.g. in Wenzhou, the private sector had surpassed its public counterparts. ${ }^{22}$

Secondly, various forms of shareholding companies, including those in which the state, collectives and individuals held shares, were encouraged to be implemented on a pilot basis. Thirdly, it allows the sale of the property of certain small soes. This policy was severely curtailed by the politically driven austerity in the aftermath of the Tiananmen incident in 1989. Privatization was criticized as a form of 'bourgeois liberalism', and public ownership was again stressed as the foundation of the socialist system. In 1992 Deng's southern tour reversed the 'leftist reversal' in reform. Using capitalism for building socialism was openly called for. This led to the adoption of a reform aiming at the establishment of a 'socialist market economy'23 in the fourteenth Party Congress. Then, it became clear that since the introduction of the reform, China had been making its way towards a 'market economy with Chinese characteristics'.

In line with the marketization objective that the fourteenth Party Congress set, a 'modern enterprise system' campaign was launched in order to make the soes independent and responsivee to the market. The thrust of the reform had concentrated on rearrangement and clarification of property rights among government agencies and publicly owned firms. In other words, China had adopted a different path of reform and established a distinction between the processes of property rights reform and de facto privatization before the fifteenth Party Congress, which took a further step forward. According to the blueprint set forth by the Party congress, some soEs would be merged with more successful partners, some would sell stock to investors or employees, some would be listed on China's stock markets, a few would go bankrupt and

22 According to a Federal Reserve Bank of Dallas report, nine out of ten Wenzhou businesses are privately owned. See Dallas Fed, 'China's churn', The Economy in Action, (September 200o), available at http://www.dallasfed.org/htm/pubs/china.html.

23 The socialist market economy is the economic model employed by the People's Republic of China. It is based on the dominance of the state-owned sector and an open-market economy, and has its origins in the Chinese economic reforms introduced under Deng Xiaoping. The ideological rationale is that China is in the primary stage of socialism, an early stage within the socialist mode of production, and therefore has to adapt capitalist techniques to thrive. 
some would be simply sold off to the private sectors. In the words of Ji Xiaonan, a State Economic and Trade Commission official, China is holding onto the big and letting go of the small (zhuada fangxiao)', a process that eventually will shrink the once-dominant state sector down to 'a few important industries'. ${ }^{24}$ According to one report, $80 \%$ of the firms at or below county level had been privatized by the end of $1998 .^{25}$ China's preparation for its entry into the WTO in 2001, which required necessary market-oriented reforms, was in part responsible for the momentum of the sov reform.

It is not surprising then that soe reform slowed from the early 200os. There was also a public backlash against the de facto privatisation given a myriad of scandals of asset stripping and rising unemployment. In response, China's State Council established the State-owned Assets Supervision and Administration Commission (SASAC) in 2003, with the mandate of SOE reforms, growing state assets, and optimising their sectoral allocation. SASAC has taken measures to strengthen its supervision of soEs, such as streamlining soes' reporting structures, and has pushed for corporate governance reforms and diversification of ownership structure for soEs. SOE consolidation has continued through merger and acquisition. However, in reality, SASAC put more emphasis on its mandate of growing and supervising state assets and even de facto supporter of large-sized soes, rather than on reforming and restructuring soes. This became evident when the soes, particularly the large-sized ones, were picked up to receive vast amount of loans, which stems from the quantitative easing policy, during the global financial crisis in 2008. 2003-2012 saw an exponential

24 See Kathy Wilhelm, 'Out of business', Far Eastern Economic Review, (11 February 1999), p. 11. Li Dongsheng, another State Economic and Trade Commission official, further elaborated that no soes shall be reformed into corporation completely owned by state-ownership in general, except for the following three kinds of soEs: (1) enterprises have to be monopolized by the state; (2) a few large-sized enterprises having conditions to be the main body of state-ownership and the state-owned capital management and operation companies or state controlled companies reformed from former governmental authorities; (3) subsidiary companies completely owned by the above-mentioned two kinds of enterprises. See Liu Dongsheng, 'System arrangement of the corporate governance of the Chinese state-owned enterprises and companies', Corporate Governance of State-owned Enterprises in China Conference Paper (sponsored by the Organization for Economic Cooperation and Development and Asian Development Bank), Beijing, 18-19 January 2000.

25 Zhao Xiao, 'Competition, public choice and privatization in China', CCER Working Paper (Series C1999025), Beijing University. 
growth of soes and state-controlled enterprises, ${ }^{26}$ and was therefore be dubbed as the Golden Decade for soEs. ${ }^{27}$

The 2012 was a turning point for SOEs and for the Chinese economy that appears to be faltering. In the latest top-down measure to restore confidence in the economy, the CPC Central Committee and the State Council jointly released the above-mentioned soe Reform Guidelines. The new soE Reform Guidelines followed the Decision on Major Issues Concerning Comprehensively Deepening Reforms, which was adopted at the close of the Third Plenary Session of the 18 th CPC Central Committee on 12 November $2013 .{ }^{28}$ Unfortunately, after the initial sensational effect, ${ }^{29}$ the Decision turned out to be "much said but little done". According to the soe Reform Guidelines, China's soes will be divided into two categories, for-profit entities and those dedicated to public welfare. The former will be market-based and operated on a commercial basis and should aim to increase state-owned assets and boost the economy, while the latter will exist to improve people's quality of life and provide public goods and services.

Mixed-ownership reform is targeted as the most significant means to improve the efficiency of soes. In this regard, the government should introduce multiple types of investors so soes can achieve mixed ownership and encourage them to go public. Non-state firms will be encouraged to join the process through various means, including buying stakes and convertible bonds from or conducting share rights swaps with soes. soes will also be allowed to experiment with selling shares to their employees.

SOE boards of directors will have greater decision-making powers, managers will be more tightly supervised, and intervention by government agencies will be forbidden under the new guideline.

Reforms in soEs have become a major task for China's policymakers during the battle against downward pressure. ${ }^{30}$ The authorities also hope that

26 Xinhua News Agency, Ten Golden Years in the 21st Century: the Past and Future of soe Reforms, 13 September 2012.

27 Hu Angang, soes' completion multiplies during the 'Ten Golden Years', Economic Daily, 8 October 2012.

28 Available at http://news.xinhuanet.com/2013-11/15/c_118164235.htm.

29 Even an article published with the Financial Times on 20 November 2013 hailed the Decision as a start of new Ten Golden Years for reform, see Liu Ligang, The New Start of A Ten-Golden-Years for China, available at http://www.ftchinese.com/story/o01053523.

30 For the 2016-2020 period, President Xi Jinping has outlined a new economic normalcy, which is characterized by a moderate annual growth rate, compared with the country's often double-digit growth in the past decades. See Propaganda Department of CPC, Understanding Series of Important Talks by Secretary General Xi Jinping, People's 
a new round of reform will modernize soes, enhance state assets management, promote mixed ownership and prevent the erosion of state assets. The SOE Reform Guidelines suggest that the goals in all the main reform areas should be accomplished by 2020, constituting a system that is more suitable to the nation's socialist-market economy.

\subsection{Rationale behind the Rounds of Chinese soE Reform}

An examination of the reform charts would reveal that China has been very cautious in reforming soEs. It is not difficult to find that the Chinese reform of soEs has adopted an incremental approach. China's economic reform policies since the late-1970s have balanced the dual objectives of enhancing economic efficiency and strengthening the position of the ruling Communist Party. While soe reforms were designed to tackle the obvious inefficiencies inherent in soEs, they needed to be done slowly in order to preserve China's political and social stability.

By the Marxist orthodox, socialist credentials are based on the fundamental ownership of state assets by the proletariat. Then a question arises: why did the Chinese leadership introduce, for example, the 'common ownership' program, aware that it would undermine the base of its rule? It is desirable to look in the guideline for reform, Deng Xiaoping's 'theory for building socialism with Chinese characteristics' and probe into the nearly two decade-long marketoriented reforms.

Despite the fact that Deng's theory, in the Chinese jargon, is hailed 'the Marxism of present-day China', it is not a result of coherent and systematic theoretical formulation itself. Deng's theory is often referred to by Westerners as an impressive 'Cat theory'. This doctrine came out long before China committed itself to reform, which literally means whichever of both a white cat and a black cat catches mice is the better one. The unique doctrine has put Deng's personal stamp on China's reform: pragmatic. Noticeably, by common sense, no systematic theoretical preparation had been made before the reform was introduced. The only build-up then in theory was a so-called 'emancipating [of] the mind and seeking truth from fact', so abstract as to be manipulated. It is clear that from the outset the reform was utilitarianism-driven.

When it came to 1992, it was made ever clearer that the Deng-labeled reform was characterized by utilitarianism. After Deng made speeches in his southern tour in order to boost the reform, his reform theory was identified as 'three favorables' criteria, which said that any policies that helped promote productivity,

Publishing House 2016, at: 141; See also, China's Economy, Coming Down to Earth, The Economist, April 15th, 2015. 
living standards and national strength should be encouraged. The conclusion needs no further proving. Most observers of China have concluded that China remains politically unchanged while pursuing market-oriented reform in its economy. To them there seems to be a tension between the regime's willingness to grant expanded autonomy and its insistence on maintaining political control. It seems to the author, however that the Chinese government has implemented somewhat consistent policies in both economic and political domains. Utilitarianism is the very philosophical instrument that combines them coherently. Utilitarianism guides not only economic reform, but political life in China as well.

With regard to reform of soes, it is understandable that, if the soes could have survived without relying on government subsidies then the Chinese leadership would have never introduced rounds of SOE reform in any sense, taking the political risk of undermining 'the basis of the socialist economic system'. A recent article published in the authoritative Qiushi magazine in the name the SASAC, which was about the implementation of the Certain Opinions on the Upholding of Party Leadership and Strengthening of Party Construction in the Reform of State-owned Enterprises by the CPC Central Committee, ${ }^{31}$ and required all important decisions of the central soe to be discussed first by the Party Committee of the soE before they can be referred to the Board of Directors of the soe concerned, ${ }^{32}$ is a clear evidence. Unfortunately the performance of the ailing soEs was from time to time so discouraging as to compel SOE reforms round after round. According to a study by the World Bank, one third of all the industrial soes lost money in 1994 while in 1996 the figure rose to a half. ${ }^{33}$ Again, the years after 2012 also witnessed a sharp decrease of revenue and profits among soes, particularly in Northeastern China. ${ }^{34}$ It is not

31 The Central Committee of CPC, Certain Opinions on the Upholding of Party Leadership and Strengthening of Party Construction in the Reform of State-owned Enterprises, 20 September 2015 .

32 SASAC, All Important Decision-making Must be Discussed by the Party prior to the Board Meeting, Qiushi (Truth-seeking), 7 June 2016.

33 See The Economists, 13-19 September 1997, p. 22.

34 The first five months of 2012 recorded a 10.4 percent decrease of profits in central soEs, see Xinhua news, 15June 2012. For the first three months, soEs and state-controlled enterprises recorded a decrease of 13.8 percent of profit decrease, see Ministry of Finance website, http://qys.mof.gov.cn/zhengwuxinxi/qiyeyunxingdongtai/201604/t20160426_1965751. html. Premier Li Keqiang called for the reversal of the trend of soes' falling efficiency at an ad hoc National Tele-conference on the mobilization to improve the quality and increase the efficiency of soes on 25 March 2016, see the website of the Central People's Government: http://www.gov.cn/guowuyuan/2016-03/26/content_5058618.htm. 
difficult to detect the correlation between the ill performance of soEs in the previous years and the launch of a new round of SOE reform thereafter. Faced with a growing number of soEs that could neither repay their debts nor create jobs for a fast-growing workforce, officials at all levels have come to view state ownership not as the crown jewel of socialism, but as a burden that must be lightened to keep the economy growing and the Communist Party holding on to power. ${ }^{35}$

Since the late 1970s, the market-oriented reforms introduced to the SOE sector over the past three decades have seen the government loosen its control over soEs, the shedding of a large number of loss-making enterprises, and significant restructuring of remaining enterprises, including by public listing. soEs were subject to greater market discipline, enjoy more autonomy, and are more accountable for their performance. However, most of these soes have clustered in those sectors that play crucial roles in the national economy such as energy, telecommunication and finances. Despite several rounds of reform on the soes aiming at a separation of governmental functions from corporate management, and a modern market-oriented governance structure, Chinese soEs remain monopolies or de facto monopolies with exclusive access to many important industries relevant to national economy and people's livelihood. Further, soes can enjoy a lot of privileges in their operation, some even have certain regulatory authority which is supposed to be exercised by the government. Such a system has widely been cited as a form of state capitalism. ${ }^{36}$ This kind of economic model is also dubbed as a non-market economy in the context of trade relations or state-led economy in the context of investment relations with the rest of the world. China's SOEs is still on a long and yet-to-be accomplished journey.

35 For an elaboration of the reasons for privatization of soes in China, see David D. Li and Francis T. Lui, Why Do Governments Dump State Enterprises? Evidence from China, Conference paper of the Twelfth Annual East Asian Seminar on Economics, Hong Kong (28-30 June 2001).

36 State capitalism is a technical term first used in the literature about international communism movement. See Lenin: A Great Calamity Is at Hand, What Is the Way Out? Lenin Selected Works Vol. 3, People's Publishing House 2012, pp. 232-237. Lenin pointed out in this article that destroying capitalism and realizing socialism is to nationalize banks and monopoly organizations, abolish trade secret, force the industrialist, merchant and entrepreneur to join in the union, and force the residence to join in the consumer's cooperative. See also Lenin Complete Works Vol. 42, People's Publishing House 1987, p. 221; Lenin Complete Works Vol. 34, People's Publishing House 1985, p. 236. 


\subsection{The Concept of State-led Economy and Chinese Model for Economic Development}

A state-led economy has always been associated with state capitalism. Since the financial crisis in 2008, some of the Western scholars have picked up this term and interpreted it based on their own understanding, so as to depict emerging economies with common characteristics, especially China.

How to cope with the state-market relationship and government-enterprise relationship lies at the core of a modern economy. In the market-oriented economy, there is a clear divide between government and enterprises. When it comes to SOEs, governments can only act as investors, while the entire operation of SOEs is left entirely to the managers who are under the guidance of the board of directors. In this case, the government shall not involve itself in soes' management. Advocates of market economy perceived state capitalism as one kind of capitalism which is, however, led by the government to manipulate the market for political consideration. ${ }^{37}$

In the system of state capitalism, governments use diverse soEs and statecontrolled enterprises ${ }^{38}$ to allocate resources, and utilize championed companies to control certain economic fields. soes are exactly established to execute national strategic goals.

If we evaluate China's government-soes relationship in this way, it seems inevitable to examine the so-called China model. The term was dubbed in 2004 by Joshua Cooper Ramo, an American consultant, playing on the idea of a declining "Washington consensus". Although scholars and officials in China are divided over whether there is a China model, the Communist Party is diffident about laying claim to any development model that other countries might copy. It is generally thought to be characterized with one-party rule, an eclectic approach to free markets and a big role for state enterprise being among its commonly identified ingredients. ${ }^{39}$

Against this backdrop, it is reasonable to call Chinese economic system as a state-led economy. For a relatively long time, China's economy has featured as semi-market owing to the obvious governmental dominance. In such special type of economic system, soEs, championed private enterprises, state-owned banks and sovereign wealth funds play a predominant role. soEs, as the tools

37 Ian Bremmer, The End of the Free Market: Who Wins the War Between States and Corporations? Portfolio, May 2010.

38 State-controlled enterprises include enterprises with governmental shares and private enterprises selected by the government.

39 For a quasi-official explanation of the Chinese model, see Study on the China Model: Analysis of Economic Development Path of China, People's Publishing House, 2009. 
available for governments to regulate economy, allocate resources and fuel economic growth, have long served as semi-governmental tools and semimarket participants. In this process, the government has played dual roles as an administrator and a market participant. Being the administrator, Chinese government has made great contributions to market management; while in contrast, as a market entity, it also safeguards its interests as the owner of over 30 trillion state capital and assets. As the owner and administrator of such a huge amount of state capital, Chinese government has to set both overall and specific plans on the allocation of resources in the forms of coal, electricity, oil and etc. To best utilize this state capital, the government has to implement differentiated treatment in the light of diverse ownerships.

Thus, state capitalism is invariably linked with China, namely Chinese state capitalism. ${ }^{40}$ Some of the occidental scholars even refer to Chinese state capitalism as the "innovative state capitalism". ${ }^{41}$ Objectively speaking, this modality matches the development stage of China and help China achieve great economic success in a short term. Nowadays, China's soes as well as their affiliated companies indeed have contributed to over half of China's GDP and employment. ${ }^{42}$ In 2015, 106 mainland China companies were included in the global list of Fortune 500. Eighty-six of the shortlisted 106 Chinese companies were soes, with 47 directly under the control of the State Assets Supervision and Administration Commission. ${ }^{43}$ Apparently, soes have played significant roles in the national economy system. With their scale effect, leading role, comparatively abundant human resources and technology reserves, soes have become major contributing factors to China's economic achievements.

However, certain flaws still exist in state-led economy, some of which are even fatal. First of all, even though most soEs have built up a corporate governance framework in China, this is still a tough issue, especially in standard running and operation efficiency. soEs or state-controlled enterprises could not

See National Intelligence Council, Global Trends 2025: A Transformed World, November 2008, available at http://www.dni.gov/files/documents/Newsroom/Reports\%20and\%20 Pubs/2025_Global_Trends_Final_Report.pdf.

See Joshua Kurlantzick, The Rise of Innovative State Capitalism, Businessweek, June 28, 2012.

42 In the end of 2013, central enterprises have total assets of 34 trillion CNY, increased by $11.7 \%$ than 2012, among which 68 enterprises have assets over 100 billion CNY; in 2013, central enterprises have operation revenue of 24.4 trillion CNY, increased by $9.1 \%$ than 2012 , among which 56 enterprises have operation revenue over 100 billion CNY. See Overall Operation Condition of Central Enterprises, issued by State-Owned Assets Supervision and Administration Commission of the State Council on July 26, 2014. 
recruit senior officers in the employment market but to accept the appointment by the Chinese Communist Party (i.e., the Organization Department of CCP). The State Commission for State Asset Administration has the authority to determine the transfer of the shares of soEs. Even though there are several disclosure rules and requirements concerning transfer of shares of listed companies, and stakeholders can also petition for remedies through derivative actions, few people have practiced them yet. As to internal governance of soEs, it is common that the soes are mastered by the insiders, thereby resulting in the fragile internal governance. Therefore, the state-led economy is lowefficient when it comes to allocation of resources.

Secondly, there might be some impediments to the sustained development of state-led economy. State-led economy means that the need of the states is given priority over that of the soes, which may easily lead to the inefficiency of enterprises and in turn restrict its development. And centralization of power may deprive the enterprises of their innovative capacity with a fear of creative destruction ${ }^{44}$ and changes brought by reforms. Furthermore, it is presumable that the abuse of the authority will enable the government to make rules selectively and then provide monopoly access for soes by excluding other private and foreign enterprises out of fair competition. The non-transparent SOE operations may also help cover politicians' failure decision in investments, which in the long run will unequivocally hurt a country's economic development.

Equally important is that China's state-led economy model places foreign investors and traders on a disadvantaged position. The American Chamber of Commerce in China, which represents the interests of part of the U.S. investors in China, for example, pointed out in its White Book U.S. Enterprises in China 2012 that foreign enterprises cannot fully participate in standard-setting in China and the procedures cannot stay transparent. ${ }^{45}$ In accordance with the regulations on Standardization Administration of the People's Republic of China, foreign enterprises registered in China are qualified to be part of

44 Joseph Alois Schumpeter pointed out, "Entrepreneurs are the leaders of economic development, and the innovators to realize recombination of production factors. Entrepreneurs are the subjects of innovation, their role is to creatively destruct market imbalance (creative destruction). Dynamic imbalance is a normal status of healthy economy (rather than balance and best allocation claimed by classical economist, while entrepreneurs are the organizers and initiators. Only through creative destruction can entrepreneurs gain the opportunity to make extra profits. See Joseph Alois Schumpeter: Theory of Economic Development, translated by He Wei, Yi Jiaxiang, The Commercial Press 1990, preface of the Chinese version.

45 American Chamber of Commerce in China, The U.S. Enterprises in China 2012 White Book, at:79, 81 . 
the standardizing agencies and participate in the standard drafting and voting. In practice, however, it is up to the technical standard-setting committees or sub-committees to decide whether relevant foreign enterprises can be included. ${ }^{46}$ Some of them do not allow foreign enterprises to participate in the process; some only allow the foreign enterprises to participate as an observer, while some of them allow foreign enterprises to participate with voting rights. These committees or sub-committees are mostly controlled by the government, which is considered as the product of state-led-economy. It demonstrates that emerging SOE provisions in the IIAs are quite relevant to the problem facing China.

In the external environment, certain soEs or even industries can grow rapidly with the assistance of the national strength under the state-led economy system. soes always enjoy more privileges or conveniences than private enterprises, and these preferential policies will enhance their competitiveness on the market, which comes rather from the government support than their own superior management or technologies. ${ }^{47}$ Among the financial supporting policies, subsidies are considered as the most direct means. Due to the special political, economic and cultural environment, during the economic reforms, China provides certain enterprises or industries or areas with needed financial support, in order to accommodate to the distortion brought by the centrally planned economy and buffer the harmful effect of economic structure adjustment on the political and social level. These financial subsidies may fall in the regulating scope of competitive neutrality, and it will not merit international investment. In these areas, China is now faced with enormous challenges. Also, sOEs is easily accessible to privileges and conveniences concerning financing and guarantee. In China's current financial system, state-owned banks are major players, and they are more inclined to issue loans to soEs. ${ }^{48}$ Also, China's interest-rate policy has been long offering subsidies to SOEs, which provided lower financing costs for lenders (mainly soEs). Under the interest-rate policy, the banks can get a $3 \%$ net interest margin, while the depositors can only get

46 E.g., China Steel Standardization Technical Committee, China National Technical Standardization Committee on Electro-acoustics, and China Financial Standardization Technical Committee.

47 ZHAO Xue-qing, WEN Han, The Influence of the Competitive Neutrality Policy on China's State-owned Enterprises, Hebei Legal Science, Vol. 31, No.1, Jan., 2013, at:33-37.

48 Godfrey Yeung, How banks in China make lending decisions, Journal of Contemporary China, Vol. 18, No 59, March 2009, pp. 285-302. 
negative real yields ${ }^{49}$ As a matter of fact, this measure has levied taxes on general public in the interest of state-owned banks and soes. ${ }^{50}$ Further, considering such factors as economic security, soes in the fields of electricity, oil and gas, telecommunications, railways, tobacco and some social services enjoy a high level of monopoly. ${ }^{51}$ Indeed, these enterprises do protect the nation's economic security, but in the long term this may facilitate industry chain monopoly, which directly impairs market competition and market access.

\section{Implications of the SOE Rules in IIAs for China's SOE Reform}

As illustrated above, the 2012 U.S. BIT model and particularly the TPP are characterized by the inclusion of the soE rules based on state-led economy presumption, which means that there are more restrictive regulations governing soes and their special treatment, and countervailing their competition implication in the host country and their home country.

Apart from creating a fair and impartial environment for the investors, this new international investment regime is, in some way, intended to alter the host country's economic governance regime and have its impact on SOE reform in the host country. This is particularly so where the SOE rules in IIAS are made on a state-led economy denomination for China

Being one of the issues around foreign investment policies, state-led economy should be based on acknowledgement as such: state-capitalism may jeopardize fair competition in the world at large due to the existence of sovereign wealth funds and large soes; also, soes' governance lacked in transparency and accountability and soes may become the instrument for their home country to abuse economic preferences and interfere with other countries' development.

49 China's interest rate is determined by the two forces of government regulation and market liberalization. Commercial banks are free to determine respectively the interest rate for saving and lendings within a range around a suggested rate. Taking the annual inflation rate $6-10 \%$ into account, depositors are net losers.

5o Interest from savings is taxable in China.

$5^{1}$ With exception, soEs or state-controlled companies are monopolizing Chinese energy, telecommunications and even high-tech industries. State Grid, Sinopec (China Petroleum), CNPC (China National Petroleum Company) and cNOoc (China National Ocean Oil Company), which are the predominant players in energy sectors, are soEs. China Telecom, China Mobile, China Unicom are the three soe high-tech giants in telecom industry. 
For China, a state-led economy denomination in the China-U.s. BIT and other IIAs amount to the fact that the U.S. and western countries make judgments over and intervene into the development path of other countries and even attempt to change the rules made by themselves. The general success of the soEs leads to a general impression among quite a number of Chinese offcials and Chinese soes that they have been reshaped in accordance with the modern corporate system with commercially viable governance structure as well as social and public responsibilities. Emerging economies such as China are joining in the economic world with rules mainly made by the Western countries, and this has consolidated their understanding that the operations of soEs are consistent with international practices. Chinese elites in general believe that the U.S. has its own interests on state-led economy issue, as in other agenda. The fact that China is to be singled out for a state-led economy denomination exactly demonstrates the strong prejudice and self-interest motives of the U.s. This action that puts political judgments in the economic field may be somehow rational in fostering fair competition. But its goal is to protect the self-interest and obstruct development of the emerging countries.

Despite the discontent, China is to accept the new BIT model. It is unlikely yet that it will be formally denominated as a state-led economy. The biggest possibility is that China is to be required to follow the SOE rules deriving from the newly emerging model IIAs, while no specific reference is made to the state-led economy denomination. That being the case, the IIAs and BITs in particular would bring China a bundle of increasing obligations under this system and an unprecedented impact on China's mode for economic development. The implications are analogous to those of the non-market economy (NME) denomination in China's wTO accession Protocol. ${ }^{52}$ As a contracting

52 The notion of non-market economy ( $\mathrm{NME}$ ) treatment, which was introduced into the General Agreement on Tariffs and Trade and the wто, has mainly been used in the antidumping investigations on certain countries. It seems to stem from the idea that nonmarket economies are fundamentally different from "market economy" as concerns the amount of hidden subsidies (publicly financed goods and services) present in those markets. Paragraph 15(a) of the Protocol on the Accession of China to the wTO protocol on China's accession to the wTO allows countries importing Chinese goods to adjust or disregard Chinese prices and costs when determining whether the imported goods are being dumped onto their markets. The constructed normal value will normally be based on costs and prices from outside the exporting country and thus are likely to be higher. The incorporation of the so-called non-market economy clause in the Protocol was for the existing Wто members to assuage the impact of anticipated massive inflow of Chinese products on the market of importing countries. China accepted the clause in exchange for an earlier conclusion of the accession package. While Paragraph 15 triggers debate in 
party, China will have to carry out a comprehensively economic reform to comply with the disciplines specified in the BIт. In that case, China will firstly meet two demands through systematic rule-remaking. One is to reduce investment barriers faced by Chinese enterprises, especially remove the political reviews over national security of host countries. And the other is to deepen reform by opening investment market. It is also understandable that the incorporation of the soe provisions in the China-U.S. BIT will in turn accelerate the domestic economic reforms. For this, China shall be prepared for the unsustainability of the state-led-economy modality and seize the opportunity to promote SOE reforms.

One of the criticisms against state-led-economy modality is its unsustainability. The soes are low-efficient, easily corrupted and lack of risk management due to the governmental leadership. The purpose of state-led-economy is to create and retain more job opportunities, realize investment payback, maintain a stable society and promote social wealth. Besides, the state-ledeconomy modality is unlikely to stimulate greater creativity in satisfaction of public demands for neoteric products and improved services. This is why stateled-economy is incapable of creating a prolonged and profound prosperity at large.

The elements that contribute to the greater economic success, such as the basis or impetus to innovation, all come from creative destruction, which involves participants, resources and ideas of decision makers. Under the prerequisite of creative destruction, once a company or a field is reconstructed with the innovation of new products and services, the customers may then be satisfied. While in a state-led-economy country, the government possesses the companies or factories which are protected by the government via the provision of mounting employments. More importantly, the elites under this system who enjoy the benefit and influence are the staunch force of this stateled-economy modality. In fact, they are afraid of creative destruction and are inclined to boycott reforms.

The state-led economy cannot sustain without limits. China has lost several advantages of maintaining the export-driven mode in this state-led-economy modality. Several years ago, the former Prime Minister Wen Jiabao has pointed out that the Chinese model is unstable, imbalanced, uncoordinated

both China and its major trade partner countries concerning whether China is a market economy or whether the price-determining methodologies would cease to be effective after 11 December 2016, it ironically and unexpectedly promote reform in China with a view to seeking a market economy recognition from its trade partners. 
and unsustainable..$^{53}$ To satisfy the needs of Chinese workers, wages have been raised, and this is cutting the cost advantage of products "Made in China". Before, low labor cost has propelled many foreign enterprises to outsource their manufacturing business to Chinese factories; however, for today, more and more Chinese enterprises are outsourcing their business to Southeast Asian countries for availability of cheaper labor force to maintain their competitive advantages.

During the three decades after the introduction of the opening up and reform policy, the Chinese government is gradually reducing its involvement in the economic development and trying to transform the economy into one that relies less on the soes and governmental investment. This requires a shift from the manufacturing industry-based economy in the last century to the innovation-based economy in this digital era. The Chinese Communist Party has proposed to deepen economic reform so that the market can play a decisive role in allocating resources. ${ }^{54}$ Correspondingly, soEs are confronted with a re-reform and the state-led economy needs a retrench.

China is a socialist country with a dubbed "socialist market economy", which is quite different from the market economy prevalent in the rest of the world. In China, the government has the will and competence to step in the management of economy. In the meantime, China is undergoing the marketization reform, but the reform was advanced primarily from bottom to top and implemented step by step, not in line with the liberalization approach dictated by the Washington Consensus. ${ }^{55}$

Nearly fifteen years ago, China took the opportunity of its WTO accession negotiation to build up its marketization reform, introduce the international standard into Chinese legal system and make the internal market more competitive. This move brings China a ten-year period for robust economic growth and a big increase in its share in global trade. ${ }^{56}$ The non-market economy

53 Speech on the meeting with Chinese and foreign journalists in Beijing Great Hall of the People, 6 March 2007; speech on the meeting with representatives (Beijing) on Chinese development, 11 March 2011; speech on the meeting with representatives (Tianjin) of the 18th Congress of the Chinese Communist Party, November 8, 2012.

54 See Xinhua News Agency: http://www.sn.xinhuanet.com/2013-11/16/c_118166672.htm.

55 John Williamson, What Washington Means by Policy Reform, in: Williamson, John (ed.): Latin American Readjustment: How Much Has Happened, Institute for International Economics 1989 .

56 Pascal Lamy, China's accession to wTo worth celebrating, Xinhua News Agency, 12 December 2011. 
denomination, though disliked by China, has as a matter of fact played a positive part in this regard.

Now, China is facing another opportunity of promoting SOE reforms through an international obligation based on the SOE rules. China-U.S. BIT and China- EU BIT are under way. This may help Chinese enterprises make overseas investment and expand their business. As a return, enterprises in the U.S. and the EU, for example, may gain greater access to China's market. This may enhance the governance of Chinese economy as well as form a rule-based bilateral investment relationship.

Chinese leaders are yearning to transform its mode for economic growth, letting the market play the decisive role in allocating resources, which is actually transforming the state-led-economy modality to market economy modality. This process may come across various barriers, especially the opposition from interest groups. The agreements on agenda, such as highly transparent standard and competitive neutrality discipline pertaining to the state-led economy issue, will help the government use the obligations in the agreements as a leverage to accelerate such reforms vis-à-vis opposing interest groups.

In both the Sino-U.s. and Sino-EU BIT negotiations, China has agreed to adopt a negative list, which means it will open all the industries for foreign investors except those specified in the negative list. In the past, the Catalogue of Industries for Guiding Foreign Investment was actually a positive list, and the foreign investors could only invest in a few industries encouraged or permitted by the government. This does not only affect foreign investors, it also disfavors Chinese private enterprises. If the government can treat the foreign investors equally, private institutions can ask for the same treatment. From the perspective of policy legitimacy, it is hard to imagine that an industry is only open to soEs and foreign investors, but not to the private enterprises. So the new BIT will be helpful for the private enterprises to invest in the industries once monopolized by soes and change the state-led economy. And the transparency requirement may be instrumental to reducing black box operations and combating corruption. Once these have been accomplished, it will become the guidelines for a new round of reform in China.

As stated above, this will enable China to combat corruption, abolish tedious supervisions, correct unfair law enforcement and reduce the privileges of soes. From the experience of China's entry into the wTo, if the soe rules can be executed in a fair manner, Chinese enterprises will become the biggest winners. Then why not accept these high standards? Of course, each of the SOE reforms has to sustain the problems of expectation, cost and bearing 
capacity, which exert impacts on the standpoint considering such items as state-led economy during the BIT negotiations.

\section{$4 \quad$ Concluding Remarks}

Reform is often regarded as being able to invigorate soes and provide the impetus for the development of market economies. It can be expected that, with the regime's legitimacy based on economic performance, China will go further down the road to soe reform. After all, it is of great significance to China's development in the foreseeable future to make use of the soes to ensure China's economic growth, job opportunities and social welfare.

There is no doubt that China has entered its most ambitious and difficult reform phase yet. However, after the launch of latest round of soE reform exemplified by 'common ownership', it becomes evident that the new SOE reform agenda can no longer be deemed as codes for the taboo 'privatization'.

With the emergence of international investment rules, which are prone to embody more and more soe provisions, the Chinese government is at the crossroad of a tough choice concerning its path for soE reform: shall it continue with the state-led-economy modality or not? A decision will in the end rest upon the government's awareness of the pros and cons of the different modes of economic growth.

It is useful to bear in mind that SOE rules in IIAs can inject inspiration and vigor to deepen China's reform, to expand its opening up, and to construct its new open economic system. As long as the soe reform is under the way, it is advisable for China to embrace soE rules in the emerging IIAs as reference for its reform, to fulfill its obligations under the IIAs that it subscribed to and to give the on-going soE reform a long-needed momentum. 